Review

\title{
COVID-19 AND OPHTHALMIC MANIFESTATIONS: REVIEW OF THE LITERATURE
}

\author{
Emilija Gjoshevska Dashtevska ${ }^{1}$, Natasha Trpevska Shekerinov ${ }^{1}$, Maja Ivanova ${ }^{1}$ \\ University Clinic for Eye Diseases, Skopje; Faculty of Medicine, Ss. Cyril and Methodius University, Skopje, \\ Republic of North Macedonia
}

Citation: Gjoshevska Dashtevska E, Trpevska Shekerinov N, Ivanova M. COVID-19 and ophthalmic manifestations: review of the literature. Arch Pub Health 2020; $12(3)$

doi.org/10.3889/aph.2020.5636

Key words: COVID-19, ophthalmic manifestations, conjunctivitis, transmission, prevention

*Correspondence: Emilija Gjoshevska Dashtevska, University Clinic for Eye Diseases, Skopie, Republic of North Macedonia. E-mail: egosevska@yahoo. couk

Received: 30-Oct-2020; Revised: 10-Dec-2020; Accepted: 13-Dec-2020; Published: 15-Dec-2020

Copyright: ${ }^{\odot 2020 .}$ Emilija Gjoshevska Dashtevska, Natasha Trpevska Shekerinov, Maja Ivanova. This is an open-access article distributed under the term of the Creative Commons Attribution License which permits unrestricted use, distribution, an reproduction in any medium, provided the origina author(s) and source are credited.

Competing Interests: The author have declared that no competing interests

\begin{abstract}
The epidemics of COVID-19 started in December 2019 in Wuhan, China, and the World Health Organization (WHO) officially declared a pandemic in March 2020. COVID-19 can also affect the eyes. Ophthalmic manifestations of the virus are not so frequent; the prevalence is about $3 \%$ up to now. Recognizing the possibility of ophthalmic transmission and manifestation of the virus is of significant importance for ophthalmologists and health workers. According to published studies, the most common ophthalmic manifestation is follicular conjunctivitis with all the symptoms and signs of viral conjunctivitis. It is usually bilateral, and patients present adenoviral-like symptoms, discomfort, foreign body sensation, redness, or they have no subjective symptoms. The symptoms are more pronounced in patients with a more severe clinical picture of the disease. One of the described non-specific manifestations of COVID-19 as an initial manifestation is keratoconjunctivitis. The effects of the virus on the retina and blood vessels have not been fully investigated, yet. It has been proven that COVID-19 can be isolated from tears and from ocular surface by PCR conjunctival swab. The most common mode of transmission is through direct contact and through aerosols. Through the nasolacrimal system, the eyes can be the entrance for respiratory infection and hematogenous spread of the virus can occur through the lacrimal gland. Early recognition of the ophthalmic symptoms by ophthalmologists as well as the other health workers during this pandemic is necessary because sometimes they can be the only manifestation of COVID-19, and on the other hand, it will lead to greater protection and prevention of the virus spreading. Prevention measures should be focused on the application of administrative protocols, personal protection and environmental control.
\end{abstract}

Преглед на литература

\section{COVID-19 И ОФТАЛМОЛОШКИ МАНИФЕСТАЦИИ: ПРЕГЛЕД НА ЛИТЕРАТУРА}

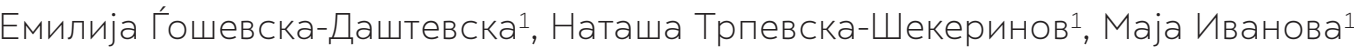

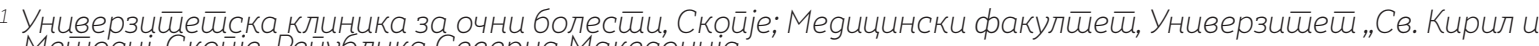 \\ мeūuoguj, Скойje, Рейублика Северна Макеgонија
}

Цитирање: Ѓошевска-Даштевска Е Трпевска-Шекеринов Н, Иванова М. COVID-19 и офталмолошки манифестации: преглед на ли тература Арх J Здравје 2020;12(3). doi.org/10.3889/aph.2020.5636

Клучни зборови: COVID-19, офталмолошки манифестации, конјунктивитис, трансмисија, превенција

*Кореспонденција: Емилија Ѓошевска-Даштевска, Универзитетска клиника за очни болести, Скопје, Република Северна Македонија. E-mail: egosevska@yahoo.co.uk

Примено: 30-окт-2020; Ревидирано:10-дек-2020 Ірифатено: 13-дек-2020; Објавено: 15-дек-2020

Печатарски права: ${ }^{\circledR 2} 2020$ Емилија Ѓошевска Даштевска, Наташа Трпевска-Шекеринов, Мај Иванова. Оваа статија е со отворен пристап дистрибуирана под условите на нелокализирана рана лиценца, која овозможува неограничен кпотреба, дисприбција и репродукција на раат оригиор(и) и изворот.

Конкурентски интереси: Авторот изјавува дека нема конкурентски интереси.

\section{Извадок}

Епидемијата на COVID-19 започна во декември 2019 година во Вухан, Кина, а пандемија беше официјално прогласена од Светската здравствена организација (C30) во март 2020 година. COVID-19 може да ги афектира и очите. Офталмолошките манифестации на вирусот не се толку фреквентни; преваленцијата досега изнесува околу 3\%. Препознавањето на можноста за офталмолошка трансмисија и манифестација на вирусот е од сигнификантно значење за офталмолозите и здравствените работници. Најчеста офталмолошка манифестација, според објавените студии, е фоликуларен конјунктивитис, со сите симптоми и знаци на вирусен конјунктивитис. Обично е билатерален, а пациентите пројавуваат симптоми слични на аденовирусен конјунктивитис, со дискомфорт, чувство на туѓ тело, црвенило или, пак, воопшто немаат субјективни симптоми. Симптомите се поизразени кај пациенти со потешка клиничка слика на болеста. Една од опишаните неспецифични манифестации на COVID-19, како иницијална манифестација, е и кератоконјунктивитис. Влијанието на вирусот врз ретината и крвните садови не се сѐ уште истражени целосно. Докажано е дека COVID-19 може да се изолира од солзите или од окуларната површина, преку брис од конјунктива со PCR.Најчестиот начин на трансмисија е преку директен контакт и преку аеросоли. Очите, преку назолакрималниот систем, може да бидат влез за респираторна инфекција, а преку лакрималната жлезда може да настане и хематогено ширење на вирусот. Неопходно е навремено препознавање на офталмолошките симптоми во време на оваа пандемија, како од страна на офталмолозите, така и од другите здравствени работници, затоа што понекогаш тие може да претставуваат единствена манифестација на COVID-19, а од друга страна, тоа ќе доведе до поголема заштита и спречување на ширење на вирусот. Мерките на превенција треба да се насочени кон применување административни протоколи, персонална заштита и контрола во средината. 


\section{Вовед}

Епидемијата од COVID-19 започна во декември 2019 во Вухан, во провинцијата Хубеи во Кина, а пандемија беше официјално прогласена од страна на Светската здравствена организација (C3O) на 11 март 2020 год., откако на 7 март 2020 год. се потврдени > 105000 дијагностицирани случаи во повеќе од 90 земји во светот. ${ }^{1}$

Корона вирусите $(\mathrm{CoV})$ се широка фамилија на вируси кои предизвикуваат болести, коишто може да варираат од вообичаена настинка до посериозни заболувања.

Постојат 4 типа на корона вируси: алфа, бета, гама и делта. Од нив алфа и бета коронавирусите $(\mathrm{CoV})$ ги инфектираат цицачите, а гама и делта - предоминантно птиците.

Корона вирусот $(\mathrm{CoV})$ се појавува три пати низ последните две декади: SARS-CoV-2 (2019), MERS-CoV (2012) и SARS-CoV-1 (2003). SARSCoV-2 (COVID-19) покажува 80\% сличност во геномските секвенци co SARS-CoV-1. Припаѓa на групата бета-коронавирус, со единечна ssRNA, што наликува на круна или шилци на површината. Шилестите протеини се врзуваат за клетките на домаќинот со ACE2 рецепторите и се реплицираат во белите дробови, срцето, интестинумот, крвните садови и мускулите., ${ }^{2,3}$

SARS-CoV-2 RNA е детектиран во примероци на крв и фецес, но досега не е потврдена феко-орална трансмисија (1). Најголемиот дел од трансмисијата од човек на човек е преку респираторни капки (Флигеови) или преку површини, со допир на своите очи, уста, нос (мукозни мембрани).

Од офталмолошка гледна точка, доказите за трансмисија на COVID-19 преку окото сѐ уште не се до крај разјаснети. Во 2004 година кон крај на SARS-CoV кризата, co PCR било докажано присуство на вирусот во солзите. Всушност, хуманиот корона вирус (HCoV-NL63) прв пат е изолиран кај 7-месечно дете со бронхиолитис и конјунктивитис, а потоа е изолиран и кај 28 деца инфицирани co HCoV-NL63, од кои 17\% имале конјунктивитис. Препознавањето на можноста за окуларна трансмисија и манифестација на вирусот е од сигнификантно значење за офталмолозите и здравствените работници. ${ }^{4}$

Од крајот на минатата година и појавата на пандемијата, повеќето студии потврдуваат дека COVID-19 може да ги афектира и очите, како форма на вирусен конјунктивитис. Еден од првите лекари кој укажа на пренесувањето на COVID-19, а подоцна за жал и почина од истиот, е офталмолог од Кина, за кој се верува дека заболувањето го добил од пациент којшто го лекувал од глауком.

Спомнатиот офталмолог, иако комплетно заштитен со протективно одело и N95 маска, сепак бил инфициран и прв симптом му бил унилатерален конјунктивитис, а за неколку часа развил и треска. Од тогаш, според СЗО, неопходно е носење заштитни очила при преглед со близок контакт со пациентот. 5,6

SARS COVID-19 е новоразвиен единечен бета-RNA корона вирус, кој предизвикува COVID-19. Вирусот е спореден со SARS (severe acute respiratory syndrome) и MERS (Middle East respiratory syndrome), кои исто така се предизвикани од корона вируси, и кои ги предизвикаа пандемиите во 2003 и 2012 година, со илјадници заболени и стотици починати. Овие две заболувања е докажано дека се шират преку директна трансмисија и респираторни капки, а исто така и преку 
загадени површини. Не се опишани случаи на окуларни заболувања, иако co PCR е докажано присуство на вирусот во солзите кај пациенти co SARS. 6

Целта на овој труд беше да се направи преглед на достапната литература за офталмолошките манифестации на инфекцијата co Covid-19.

\section{Материјал и методи}

За таа цел извршивме пребарување во базите на податоци PubMed и Google Scholar, користејќи ги следните клучни зборови: Covid-19, офталмолошки манифестации, конјунктивитис, трансмисија и превенција. Периодот на публикување на трудовите беше ограничен на 2019 и 2020 година. Со пребарувањето откривме вкупно 171 научни публикации, од кои 21 беа репрезентативни и дадоа опсежни значајни информации за ова „ново заболување”.

\section{Резултати}

\section{Начин на трансмисија}

Офталмолошка манифестација на COVID-19 е фоликуларен конјунктивитис, кој е опишан и како иницијален или супсеквентен симптом кај позитивните пациенти. Докажано е и присуство на вирусот во солзите, преку брис од конјунктива со PCR. Tоа значи дека вирусот може да се пренесува преку контакт со окуларна мукоза, солзи или контаминирани предмети. Пациентите со конјунктивитис кои имаат температура и други можни симптоми на COVID-19 задолжително треба да се евалуираат. ${ }^{7,8}$

Назолакрималниот систем е опишан како преносител на вирусот од окото до респираторниот систем, а опишана е и улогата на лакрималната жлезда во хематогеното ширење. ${ }^{9}$
Трансмисијата во суштина може да биде преку: директна инокулација на конјунктивата преку инфицирани капки, миграција од горниот респираторен тракт преку назолакрималниот канал и хематогена инфекција на лакрималната жлезда. ${ }^{10}$

Во друга студија се разгледани ваквите заклучоци и е направена анализа воопшто за начинот на интеракција на конјунктивата со вирусот и начинот на трансмисија. SARS COVID-19 е во интеракција со ACE2 и трансмембран-протеаза серин 2 (TMPRSS2), на површината на епителните клетки. Конјунктивалните и корнеалните епителни клетки ги имаат и двете компоненти, што укажува на тоа дека вирусот ги афектира овие структури. Меѓутоа ако е тоа така, тогаш стапката на зафатеност немаше да биде толку мала $(0,8 \%)$, и конјунктивалната трансмисија ќе беше најчест начин на пренос.

Ова се поврзува со фактот дека ACE2 рецепторите се во многу помал степен на окуларната површина отколку на респиратирната, а исто така и врзувачката моќ им е помала. Хепаран сулфат протеогликанот во солзите е важен помошник во поврзувањето со ACE2 рецепторите, меѓутоа ова го спречува лактоферинот (ензим во солзите). Исто така, своја улога може да има и IgA, којшто го неутрализира вирусот, што е докажано во претходни испитувања на животни. ${ }^{11}$

\section{Клинички манифестации и третман}

Во сите досегашни студии, офталмолошката манифестацијата на COVID-19 е слична на сите вирусни манифестации на окото (аденовируси). Обично се билатерални, а пациентите пројавуваат симптоми слични на аденовирусен конјункти- 
витис, со дискомфорт, чувство на туѓо тело, црвенило или, пак, воопшто немаат субјективни симптоми. Клиничката манифестација е со конјунктивална конгестија, фоликуларен конјунктивитис и обично се билатерални. Обично симптомите се поизразени кај пациенти со потешка клиничка слика на болеста. ${ }^{12}$

Неколку студии укажуваат на појавување симптоми пред петтиот ден од манифестирање на болеста, и конјунктивална конгестија поизразена по 8-от ден, до 12-от ден, со солзење и конгестија.

Како симптоми на COVID-19, според обработените податоци од различни истражувања, се наведени: билатерален фоликуларен конјунктивитис, чувство на туѓо тело, епифора (Chen L., et al.), конјунктивална конгестија (Guan WJ., et al.), чешање, чувство на туѓо тело, епифора, конјунктивална хиперемија, суво око, секреција (Hong N., et al.), билатерален конјунктивитис, фотофобија, водена секреција, хемоза, и псевдомембрани (Salucci M., et al.). 4, 13, 14, 15, 16

Во диференцијалната дијагноза на COVID-19 конјунктивитис влегуваат: други вирусни конјунктивитиси (аденовирусен), бактериски конјунктивитис, алергиски конјунктивитис, херпес симплекс кератитис, преден увеитис, корнеална абразија, туѓо тело и суво око. ${ }^{5}$

Третманот на конјунктивитисот како и кај другите вирусни конјунктивитиси е или самолимитирачки или симптоматски третиран. Кај пациентите кои немаат симптоматски потешкотии, доволно е користење на вештачки солзи без конзерванс, ладни облоги и лубрикантен гел. Се препорачува краткотрајно користење на антибиотици заради превенција од суперинфекција, особено кај пациенти со контактни леќи.

\section{Дискусија}

За да се размножуваат во домаќинот, вирусите мора првин да се спојат со рецепторите на клетката. Кај корона вирусот ова се случува преку шилест протеини, кои поминуваат преку липидната обвивка, а како рецептори ги користат ангиотензин конвертирачките ензим-2 рецептори (АСЕ2 рецептори), потпомогнати од серин протеаза (TMPRSS2). Конјунктивата нормално има ACE2 рецептора, но нема серин протеаза, така што теоретски, невозможно е вирусот да се врзе за конјунктивата. Во секој случај, можно е вирусот да дојде во контакт со окуларната површина, со солзите да биде пренесен во назолакрималниот канал, во назофаринксот и понатаму во респираторниот или гастроинтестиналниот систем (ГИС). Ова е трансмисијата на вирусот преку окуларна површина. ${ }^{17,18}$

Неколку објавени студии сугерираат на засегање на артериската и венска циркулација, вклучувајќи и ретинални оклузии и мозочни удари. Сепак, не се до крај разјаснети овие тврдења.

Во една студија се прикажани 12 пациенти со потврден COVID-19, кај кои имало абнормалности на наодот на оптичката кохерентна томографија на задниот сегмент (OCTPS), хиперрефлективни лезии на ниво на слојот на ганглиските клетки, внатрешниот плексиформен слој, особено во папило-макуларниот сноп. Кај 4 пациенти од наведените, при преглед на очното дно биле присутни и меки ексудати и микрохеморагии. Сите пациенти имале нормална видна острина.

Конјунктивални примероци од солзи биле испитувани кај инфицирани лица, позитивни на SARS-CoV-2 RNA, со или без симптоми, со реверзна-транксриптаза PCR (RT-PCR). 
Интересен заклучокот дека степенот на трансмисија преку солзи бил низок.

Една од причините зошто офталмолошките манифестаци се со мал процент е имуниот систем на окото. ${ }^{18,19,20}$

Се смета дека детекција на вирусот во солзите е до 3 дена, додека според некои автори и до 2 недели. RTPCR тест, кој обично се користи за докажување на вирусот во солзите или конјунктива, е со мала сензитивност, и негативен резултат не значи дека вирусот не е присутен, особено кај пациенти со симптоми.

Во студија со вклучени 36 пациенти со потврден COVID-19, поделени во група со конјунктивитис и група без конјунктивитис, преку брис од конјунктива било потврдено присуството на вирусот само кај двајца пациенти, по еден од секоја група, односно кај 5.5\% од испитаниците. Ова значи дека вирусот може да се детектира и кај пациенти со конјунктивитис и кај оние без, во ист сооднос.

Офталмолошките манифестации на вирусот не се толку фреквентни, а начините на трансмисија се сѐ уште контроверзни и во секој случај се сведуваат на зафаќање на окуларната површина. Неколку студии опишуваат неспецифични манифестации на COVID-19 како прва манифестација, а една од нив е кератоконјунктивитис. ${ }^{17,18}$

Детекција, квантификација и детерминација на вируленцијата е со земање примерок и тестирање со култура-базирани (ICC-PCR) или молекуларно-базирани процедури (RTPCR, PCR, dPCR, Nested PCR, NGS, MALDI-TOF). Вирусите со обвивка како COVID-19 се понестабилни на оксиданси за разлика од необвитканите вируси, па така конвенцио- налните методи на хлоринација, озонација, водород пероксид, хипохлорат и РРА заедно се соларна и УВ радијација се најчесто користени методи за оштетување на вирусната обвивка. ${ }^{2,3}$

Потребно е да се направи дезинфекција на заштитниците на биомикроскоп со 70\% алкохол по преглед на секој пациент, како и на сондата од ултразвук и другите алатки, а Голдмановите тонометри да се стерилизираат со $10 \%$ натриум хипохлорид. $^{5}$

\section{Заклучок}

COVID-19 пандемијата која го зафати целиот свет се одрази како на здравството, така и на економскиот и социјалниот живот, и индиректно воведе нов начин на комуницирање меѓу луѓето, нов начин на прегледување на пациентите и нови хигиенски навики. Во секој случај, се препорачува што е можно повеќе избегнување физички контакти, скратено време на комуникација со пациентите, избегнување на одредени дијагностички методи и воведување нови.

Оваа пандемија се одрази и во сферата на офталмологијата. За среќа, поголем дел од офталмолошките манифестации се конјунктивитиси, кои се самолимитирачки или се третираат со симптоматска терапија. Неопходно е навремено да се помисли на офталмолошките манифестации како прва одлика на овој вирус, затоа што окото учествува во трансмисијата на вирусот.

Исто така, неопходно е почитување на светските протоколи за заштита, со цел заштита на пациентите меѓусебно, како и заштита на здравствениот персонал. 


\section{Препораки}

Несомнено справувањето со пандемијата зависи од добрата соработка и координираните напори на локално, институционално, регионално и национално ниво.

Примарно е следењето и евидентирањето на лицата заразени во средината, нивно идентификување, односно спроведување на мерки на претпазливост од пренесување со цел да се намалат можностите за трансмисија и превенција, пред сѐ на здравствените работници кои се директно изложени на ризик.

Потребно е: да се применуваат стандарди за претпазливост со сите пациенти; да се применуваат мерки на претпазливост при контакт со лица суспектни за SARS-CoV-2; да се следат контактите на пациентите; да се воспостават соодветни административни контроли и политики преку обука на персонал, ресурси, простор итн., сѐ со цел ширењето да се сведе на минимум.

Препораките за заштита се насочени кон тријажа на пациентите, навремено детектирање на суспектно инфицираните пациенти, максимална заштита, особено на ризичните пациенти и што пократко време на задржување со пациентот. Мерките на превенција се поделени како: административна контрола, контрола на средината и персонална заштита.

Административната

контрола

вклучува: презакажување на неитни прегледи, тријажа, пополнување прашалници од страна на пациентите, проверка на телесна температура, избегнување контактни методи, односно неконтактно мерење на интраокуларниот притисок (ИОП) со примена на тонопен, избегнување аеросол-поврзани процедури, како воздушен тонометар, намалу- вање на бројот на вработени на неопходен, намалување на времето на чекање и преглед на минимум, користење дијагностички методи само доколку се неопходни, хируршките интервенции да се тријажираат според ургентност, промовирање телемедицина за консултации, користење индиректна офталмоскопија за фундус преглед, намалување размена на документи, и во случај на позитивен пациент примена на мултиклинички пристап.

Ce препорачува пациентите да бидат информирани, а оние со конјунктивитис да се прегледуваат во изолирана просторија, да се врши дезинфицирање на рацете по секој допир на окото на пациентот, и да се користат единечни, односно игли за една употреба за транспортабилен тонометар. 6 , 7, 20, 21

Контрола на средината: вентилација, протективни заштитници на биомироскоп, да се избегнува зборување за време на прегледот, дезинфекција на просторијата и апаратите со претходно поставен протокол, стерилизација со УВ ламби.

Персонална заштита: универзална маска, хируршка маска кај неризични пациенти, N95 кај суспектни и кај аеросол-поврзни процедури, заштитни очила, штитник за лице, долги ракавици кај суспектни пациенти; пациентите исто така треба да носат ракавици и маска за време на прегледот, редовно да се мијат рацете со сапун и вода, алкохол, гел, тестирање на симптоматски вработени и самоизолација, да се избегнува допирање на очите, носот и устата, профилактичко користење на хидроксихлорокин под медицинска супервизија. ${ }^{20,21}$ 


\section{Референци}

1. World Health Organization. COVID-19 Situation Reports. https:// www.who.int/emergencies/diseases/novel-coronavirus-2019/situation-reports

2. Willcox MDP, Walsh K, Nichols JJ, Morgan PB, Jones LW. The ocular surface, coronaviruses and COVID-19. Clin Exp Optom 2020; 103: 418-424. doi:10.1111/cxo.13088

3. Mohan SV, Hemalatha M, Kopperi H, Ranjith I, Kumar AK. SARS-CoV-2 in environmental perspective: Occurrence, persistence, surveillance, inactivation and challenges. Chem Eng J 2021;405:126893. Published online 2020 Sep 4. doi:10.1016/j. cej.2020.126893

4. Ho D, Low R, Tong L, Gupta V, Veeraraghavan A, Agrawal R.COVID-19 and the Ocular Surface: A Review of Transmission and Manifestations. Ocular Immunology and Inflammation 2020; 28(5): 726-734. doi: 10.1080/09273948.2020.1772313

5. $\mathrm{Hu}$ K, Patel J, Patel BC. Ophthalmic Manifestations Of Coronavirus (COVID-19) [Updated 2020 Aug 8]. In: StatPearls [Internet]. Treasure Island (FL): StatPearls Publishing; 2020 Jan-. https://www.ncbi.nlm. nih.gov/books/NBK556093/

6. Olivia Li J-P, Chiu Lam DS, Chen Y, Wei Ting DS. Novel Coronavirus disease 2019 (COVID-19): The importance of recognising possible early ocular manifestation and using protective eyewear. Br J Ophthalmol 2020;104: 297-298.

7. Dockery DM, Rowe SG, Murphy MA, Krzystolik MG. The Ocular Manifestations and Transmission of COVID-19: Recommendations for Prevention. J Emerg Med 2020;59(1):137-140. doi: 10.1016/j. jemermed.2020.04.060

8. Hoenig LJ. The eye and COVID-19 pandemic. Clinics in dermatology 2020;38(4): 506. https://doi. org/10.1016/j.clindermatol.2020.03.013
10. AmestyMA, Alió del BarrioJL, Alió JL. COVID-19 disease and ophthalmology: An update. Ophthalmol Ther 2020; 9: 415- 426. https://doi. org/10.1007/s40123-020-00260-y

11. Ali MJ. The SARS-CoV-2, tears, and ocular surface debate: What we know and what we need to know. Indian J Ophthalmol 2020;68:1245-6.

12. Wu P, Duan F, Luo C, Liu Q, Qu X, Liang L, Wu K. Characteristics of ocular findings of patients with coronavirus disease 2019 (COVID-19) in Hubei Province, China. JAMA Ophthalmol 2020;138(5):575$578 . \quad$ doi:10.1001/jamaophthalmol.2020.1291

13. Chen L, Liu M, Zhang Z, Qiao K, Huang T, Chen M, et al. Ocular manifestations of a hospitalized patient with confirmed 2019 novel coronavirus disease. Br J Ophthalmol 2020; 104:748-751. doi: 10.1136/ bjophthalmol-2020-316304

14. Guan W-J, Ni Z-Y, Hu Y, Liang W-H, Ou C-Q, Jian-Xing He J-X , et al. Clinical characteristics of Coronavirus disease 2019 in China. N Engl J Med, 2020;382(18):1708-1720. doi: 10.1056/NEJMoa2002032

15. Hong N, Yu W, Xia J, ShenY, Yap M, Han W. Evaluation of ocular symptoms and tropism of SARS-CoV-2 in patients confirmed with COVID-19. Acta Ophthalmol 2020; 98: e649e655. doi:10.1111/aos.14445

16. Salducci M, La Torre G. COVID-19 emergency in the cruise's ship: a case report of conjunctivitis. Clin Ter 2020; 171(3): e189-91. doi:10.7417/ CT.2020.2212

17. Gharebaghi R, Moshirfar M, Desuatels J, Parvizi M, Daryabari S-H, Heidary F, COVID-19: Preliminary Clinical Guidelines for Ophthalmology Practices. Med Hypothesis Discov Innov Ophthalmo 2019; 9(2): 149-158.

18. Güemes-VillahoN, Burgos-Blasco B, Arribi-Vilela A, Arriola-Villalobos $\mathrm{P}$, Rico-Luna CM, Cuiña-Sardiña R, 
et al. Detecting SARS-CoV-2 RNA in conjunctival secretions: Is it a valuable diagnostic method of COVID-19? J Med Virol 2020; $1-6$. https://doi.org/10.1002/jmv.26219

19. Seah IYJ, Anderson DE, Kang AEZ, Wang L, Rao P, Young BE, et al. Assessing viral shedding and infectivity of tears in coronavirus disease 2019 (COVID-19) patients. Ophthalmol 2020. doi: 10.1016/j. ophtha.2020.03.026

20. Lawrenson JG, Buckley RJ. COVID-19 and the eye. Ophthalmic Physiol Opt 2020; 40: 383- 388. https://doi. org/10.1111/opo.12708

21. Olivares-de Emparan JP, Sardi-Correa C, López-Ulloa JA, Viteri-Soria J, Penniecook JA. Jimenez-Román J, Lansingh VC. COVID-19 and the eye: how much do we really know? A best evidence review. Arq Bras Oftalmol 2020; 83(3):250-61. 